\title{
A Case of Grass Inflorescence Aspiration: A Novel Route from the Mouth to the Chest Wall
}

\author{
Pisi Pisi Otu Aspirasyonu Olgusu: Ağızdan Göğüs Duvarına Yeni Bir Yol \\ Ahmet Sami Bayram', Hüseyin Melek', Funda Coşkun²
}

\begin{abstract}
An unusual route of grass inflorescence aspiration from the mouth to the chest wall is described in this case. A 14 -year-old boy, with a history of grass inflorescence (Hordeum murinum) aspiration some 2 weeks prior, was referred to the clinic due to a chest wall abscess. After routine diagnostic approaches, abscess drainage, wedge resection of the affected lung lobe, and removal of the foreign body were performed using video-assisted thoracic surgery. On postoperative day 16, the patient was discharged without any complication.
\end{abstract}

Key words: Grass inflorescence, lung, chest wall, abscess.

\section{Özet}

Bu olgu ile ağızdan göğüs duvarına yeşil çiçek aspirasyonunun alışılmamış bir yolunun tanımlanması amaçlandı. İki haftalık pisi pisi otu (Hordeum murinum) aspirasyonu şikâyeti olan 14 yaşında bir erkek çocuk göğüs duvarı apsesi nedeniyle kliniğimize sevk edildi. Rutin tanısal yaklaşımlar sonrasında apse drenaiı, video yardımlı toraks cerrahi kullanarak etkilenmiş akciğer lobunun kama rezeksiyonu ve yabancı cismin çıkarılması gerçekleştirildi. Hasta herhangi bir komplikasyon olmaksızın postoperatif 16. günde taburcu edildi.

Anahtar Sözcükler: Pisi pisi otu, akciğer, göğüs duvarı, abse.
Foreign body aspiration is a common problem that can lead to accidental death among children (1). However, the aspiration of grass inflorescence is rare. Due to interesting migration through the bronchial tree, unusual clinical pictures of aspirated inflorescence have been reported in the literature (2). This case of grass inflorescence aspiration illustrates a novel aspiration route from the mouth to the chest wall.
'Department of Thoracic Surgery, Uludağ University Faculty of Medicine, Bursa, Turkey

${ }^{2}$ Department of Chest Disease, Uludağ University Faculty of Medicine, Bursa, Turkey
'Uludağ Üniversitesi Tıp Fakültesi Göğüs Cerrahisi Anabilim Dalı, Bursa

${ }^{2}$ Uludağ Üniversitesi Tıp Fakültesi Göğüs Hastalıkları Anabilim Dalı, Bursa

Submitted (Başvuru tarihi): 21.02.2017 Accepted (Kabul tarihi): 13.03.2017

Correspondence (iletişim): Ahmet Sami Bayram, Department of Thoracic Surgery, Uludağ University Faculty of Medicine, Bursa, Turkey

e-mail: asbayram@gmail.com

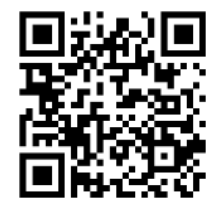




\section{CASE}

A 14 -year-old boy was admitted to the hospital with a 4 day history of fever and pain and swelling on the left side of the chest wall. The patient had a history of grass inflorescence aspiration approximately 2 weeks prior to admission. Upon physical examination, he was febrile $\left(38.5^{\circ} \mathrm{C}\right)$, with a painful induration, redness, and sensitivity on the left side of his chest wall. His white blood cell count was 16,000 cells $/ \mathrm{mm}^{3}$, with $68 \%$ neutrophils. Thoracic computed tomography $(\mathrm{CT})$ revealed marked soft tissue swelling on the left posterior chest wall, with a hypodense area suggestive of a foreign body. There was also focal consolidation in the posterior basal segment of the left lower lobe, adjacent to the soft tissue swelling (Figure 1).

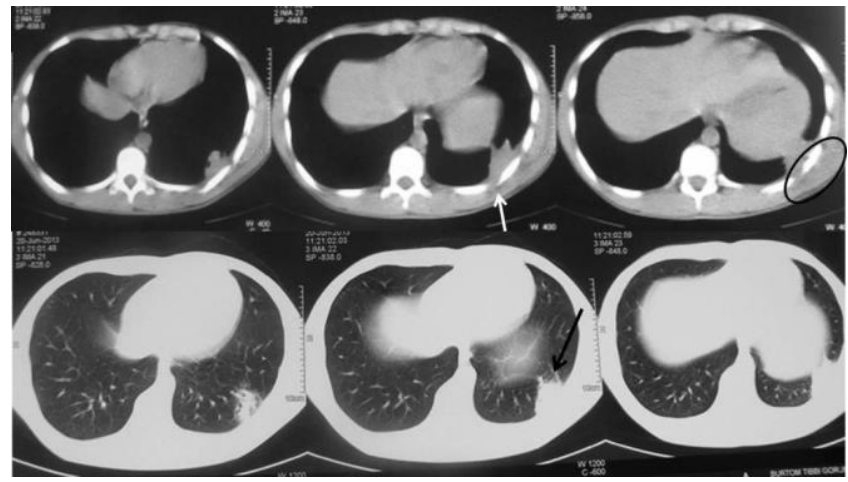

Figure 1: Computed tomography image. The white arrow indicate a foreign body on the left posterior chest wall, the black circle illustrates the abscess on the chest wall, and the black arrow shows consolidation of the left lower lobe posterior basal segment

After 3 days of treatment with ampicillin-sulbactam and ornidazole, bronchoscopy was performed. There was no sign of foreign body after the abscess on the chest wall was drained and the left lower lobe posterior basal segment with the grass inflorescence was wedge resected using video-assisted thoracic surgery (Figure 2). Postoperative antibiotic therapy was administered for approximately 15 days according to antibiogram and advice of a pediatric doctor, and the patient was discharged without complications on postoperative day 16 .

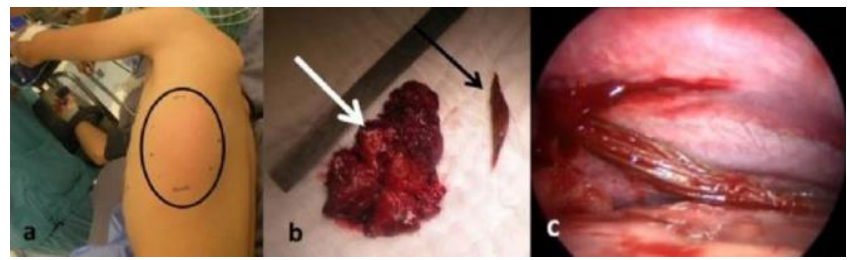

Figure 2: The abscess on the left chest wall (a), Lung with wedge resection (white arrow) and grass inflorescence (black arrow) (b), Appearance of the grass inflorescence during video-assisted thoracic surgery (c)

\section{DISCUSSION}

Grass inflorescences are uncommonly aspirated foreign bodies that can cause a range of clinical presentations because of their characteristic morphological and botanical features. These foreign bodies can migrate throughout the tracheobronchial tree (2), and 2 distinct clinical case types have been defined. The first is the "lodging" type, in which the inflorescence remains in the respiratory tract, and the other is the "extrusive" type, in which the inflorescence migrates to the periphery of the lung, penetrates the pulmonary parenchyma, pleural layers and intercostal muscles, and finally, protrudes through the skin of the chest wall (3). The present case was classified as the extrusive type because the inflorescence migrated to the peripheral lung lobe and then to the chest wall.

The spikelets of barley grass are firm, short, and set at an acute angle to a rigid stem. If the spikelets are stiff and do not soften when moistened, respiratory and coughing actions can cause the inflorescence to move forward penetrate the lung tissue, and ultimately extrude through the chest wall, as in the present case. Thus, inflorescences of this species can migrate into the periphery of the lung beyond the range of the bronchoscope (3).

The duration of the clinical course from inhalation of the inflorescence to resolution of the problem varies. For instance, the period from inhalation to extrusion of the inflorescence from the chest in 1 case was less than 2 weeks. In another 2 cases, the clinical course was 10 days (4). In our case, the length of time was between 10 and 14 days.

If the inflorescence become lodged in a major bronchus, the symptoms will generally be more pronounced, and bronchoscopy is likely to be performed earlier, when the grass inflorescence can be seen and removed. After the inflorescence has migrated to the smaller bronchi, which may occur very rapidly, it may not be seen with bronchoscopy (3). Chest CT findings are useful for early diagnosis of grass inflorescence aspiration (5), as in the present case, and these findings assist in surgical planning.

In conclusion, grass influence aspiration is a rarely encountered foreign body aspiration, and one which cannot always be diagnosed with bronchoscopic and radiological examination. CT can facilitate precise, early diagnosis Grass inflorescence moves in a forward direction due to specific botanical features; thus, its migration to other organs should be thoroughly investigated. 


\section{CONFLICTS OF INTEREST}

None declared.

\section{AUTHOR CONTRIBUTIONS}

Concept - A.S.B., H.M., F.C.; Planning and Design A.S.B., H.M., F.C.; Supervision - A.S.B., H.M., F.C.; Funding - A.S.B., H.M.; Materials - F.C.; Data Collection and/or Processing - A.S.B.; Analysis and/or Interpretation - A.S.B., F.C.; Literature Review - H.M.; Writing - A.S.B., F.C.; Critical Review - H.M.

\section{YAZAR KATKILARI}

Fikir - A.S.B., H.M., F.C.; Tasarım ve Dizayn - A.S.B., H.M., F.C.; Denetleme - A.S.B., H.M., F.C.; Kaynaklar A.S.B., H.M.; Malzemeler - F.C.; Veri Toplama ve/veya İsleme - A.S.B.; Analiz ve/veya Yorum - A.S.B., F.C.; Literatür Taraması - H.M.; Yazıyı Yazan - A.S.B., F.C.; Eleştirel Inceleme - H.M.

\section{REFERENCES}

1. Hammer J. Acquired upper airway obstruction. Paediatr Respir Rev 2004; 5:25-33. [CrossRef]

2. Karagöz B, Köksal Y, Varan A, Haliloğlu M, Ekinci S, Büyükpamukçu M. An unusual case of grass inflorescence aspiration presenting as a chest wall tumour. Pediatr Radiol 2006; 36:434-6. [CrossRef]

3. Hilman BC, Kurzweg FT, McCook WW Jr, Liles AE. Foreign body aspiration of grass inflorescences as a cause of hemoptysis. Chest 1980; 78:306-9. [CrossRef]

4. Choremis C, Theodorou S, Athanasiades T, Katerelos H. Spontaneous elimination of inhaled grass inflorescences through the lung and chest wall. Arch Dis Child 1964; 39:406-8. [CrossRef]

5. Cankorkmaz L, Köylüoğlu G, Atalar MH, Güney C, Arslan MS. An interesting journey of a grass inflorescence from broncho to dorsum: case report. Tuberk Toraks 2010; 58:89-92. 